\title{
Аналіз критичності під час протікання важкої аварії у басейнах витримки відпрацьованого ядерного палива ВВЕР-1000
}

— Білодід Євген Ігорович, канд. техн. наук Державне підприємство «Державний науково-технічний центр з ядерної та радіаційної безпеки», м. Київ, Україна ORCID: https://orcid.org/0000-0002-7790-2913

- Дудка Олена Олександрівна

Державне підприємство «Державний науково-технічний центр з ядерної та радіаційної безпеки», м. Київ, Україна ORCID: https://orcid.org/0000-0002-8973-1883

- Ковбасенко Юрій Петрович, канд. техн. наук Державне підприємство «Державний науково-технічний центр з ядерної та радіаційної безпеки», м. Київ, Україна ORCID: https://orcid.org/0000-0002-0674-6263

У статті розглянуто результати розрахункового аналізу критичності відсіку басейну витримки для реакторів ВВЕР-1000 на різних стадіях протікання важкої аварії.

Аналіз критичності паливомістких систем, що утворюються під час розвитку важкої аварії, розглянуто на прикладі дискретних конфігурацій, які можна описати певними моделями. Звичайно, у реальності протікання важкої аварії являє собою безперервний процес переходу від початкової стадії аварії до іії сталого стану наприкінці. Проте, залежно від характеристик палива та умов протікання аварії, будь-яка розглянута конфігурація з тепловидільними збірками та матеріалами басейну витримки може стати кінцевою. У статті наведено аналіз критичності відсіку басейну витримки реакторної установки з ВВЕР-1000 на етапах важкої аварії, що настають після початкової стадії аварії, коли внаслідок випаровування води та підняття температури відбувається деформація твелів та тепловидільних збірок.

На основі створених з використанням коду KENO-VI з послідовності для аналізу критичності CSAS6 пакета кодів SCALE версії 6.2.4 моделей були досліджені розмножуючі властивості відсіку басейну витримки в умовах деградації шестигранних чохлів. У розглянутих конфігураціях водо-уранової суміші була досягнута надкритичність (себто коефіцієнт розмноження нейтронів перевищив 1). Тобто, за таких умов необхідний рівень підкритичності може бути забезпечений додаванням до води розчину бору. Розглянута в рамках розвитку аварії гомогенна одношарова та двошарова модель розтікання коріуму опорною плитою $є$ безпечною з погляду на критичність. Проте, опорна плита має отвори для проходу теплоносія у тепловидільну збірку. У разі, коли розплав або уламки палива потраплять через отвори в простір під опорну плиту, вони можуть утворити із залишками води уран-водну суміш, яка за певних співвідношень палива та води, може стати надкритичною. У такому випадку розмножуючі властивості відсіку басейну витримки будуть залежати від вмісту домішків конструкційних елементів басейну витримки та тепловидільних збірок у матеріалі під опорною плитою та/або концентрації борної кислоти у воді. Після пошкодження облицювання підлоги відсіку басейну витримки, починається проплавлення бетону. Розглянуті конфігурації та матеріальний склад суміші коріуму, бетону та води дозволяють зробити висновок про безпечність цієї фази важкої аварії з погляду на критичність.

Ключові слова: SCALE, KENO-VI, басейн витримки, важка аварія, BBEP-1000, критичність, розплав, ядерна безпека.

с Білодід Є. І., Дудка О. О., Ковбасенко Ю. П., 2021 


\section{Вступ}

Під час розробки керівництв з управління важкими аваріями, оцінки характеристик джерел іонізуючого випромінювання та радіоактивних матеріалів використовуються результати детерміністичного аналізу важких аварій, зокрема можливості досягнення критичності.

Тому, під час аналізу сценаріїв важкої аварії важливо визначити умови та можливість виникнення у пошкодженому чи розплавленому паливі самопідтримувальної ланцюгової ядерної реакції на всіх етапах розвитку важкої аварії. Необхідність визначення умов та можливості досягнення критичності в аварійних умовах у паливних системах стосується як активної зони реактора (Ак3), так і систем поводження з ядерним паливом. Досягнення стану критичності в аварійних паливних системах може докорінно змінити характер перебігу та наслідки аварії через вивільнення значної кількості додаткової енергії.

Про необхідність аналізу критичності в процесі розробки керівництв з управління важкими аваріями (за результатами стрес-тестів, як заходів підвищення безпеки ядерних установок після аварії на АЕС «Фукусіма-1» [1]) наголошувалось у національних доповідях Франції, Німеччини, Іспанії, Фінляндії, Швеції, Словаччини [2] - [7] тощо, а також у підсумковому огляді результатів стрестестів, представленому Групою європейських регуляторів у сфері ядерної безпеки (European Nuclear Safety Regulators Group, ENSREG) [8].

У розроблених на сьогодні документах щодо важких аварій у приреакторних басейнах витримки (БВ) ядерного палива атомних електричних станцій (AEC) України такий аналіз відсутній. Це не дозволяє зробити позитивний висновок щодо повноти й достатності виконаного аналізу та розроблених стратегій з управління важкими аваріями. Відповідно до планів Державного підприємства «Національна атомна енергогенеруюча компанія «Енергоатом»» (ДП «НАЕК «Енергоатом») розрахунковий аналіз перебігу важких аварій [9] буде доповнено розрахунками критичності на всіх етапах розвитку важкої аварії у БВ реакторної установки (РУ) з реакторами ВВЕР-1000. Враховуючи це та необхідність забезпечення процесу оцінки ядерної та радіаційної безпеки на сучасному рівні, головною метою роботи, результати якої викладені у цій статті, $\epsilon$ розвиток можливостей Державної інспекції ядерного регулювання України (Держатомрегулювання) у виконанні незалежних оцінок критичності систем зберігання свіжого та відпрацьованого ядерного палива на всіх етапах розвитку важкої аварії.

Робота, результати якої наведені в цій статті, була виконана за фінансової підтримки уряду США [10].

\section{1 Вибір початкових та розрахункових} параметрів

Для виконання розрахунків була використана послідовність для аналізу критичності CSAS6 пакета кодів SCALE версії 6.2.4, яка забезпечує розрахунок необхідних нейтронно-фізичних констант для заданої геометрії моделі і, власне, розрахунок коефіцієнта розмноження нейтронів 3 використанням коду KENO-VI та 56-групової бібліотеки ядерних даних, основаної на файлах оцінених даних ENDF/B-VII.1 [11]. У кожному розрахунку відстежувалось 60 млн історій нейтронів, що дозволяє адекватно і з достатньою точністю змоделювати нейтронно-фізичні властивості розглянутих паливних систем. Результати розрахунків наведені у формі « $\mathrm{k}_{\text {eф}} \pm \sigma »$, де $\sigma$ - стандартне відхилення значення ефективного коефіцієнта розмноження нейтронів $\left(\mathrm{k}_{\text {eф}}\right)$ методом Монте-Карло.

Нині на енергоблоках АЕС України з реакторами ВВЕР-1000 зараз використовується паливо TВ3А виробництва АТ «ТВЕЛ» [12] та TB3-WR компанії Westinghouse [13].

Для визначення типу палива, що буде використовуватись під час подальшого аналізу, було виконано порівняльні розрахунки розмножуючих властивостей TB3A та TB3-WR. Розрахунки виконувались для моделі у вигляді сфери з палива та різним вмістом води, гомогенно перемішаної 3 паливом. За результатами аналізу обидва типи палива мають дуже схожі розмножуючі властивості, відхилення склало не більше 543 рст. Максимальне значення коефіцієнта розмноження нейтронів було отримано для $\mathrm{V}_{\mathrm{UO2}} / \mathrm{V}_{\mathrm{H} 2 \mathrm{O}}=0,2$. Отже, для розрахунку коефіцієнта розмноження нейтронів під час протікання важкої аварії несуттєво, який тип палива використовувати. Тому, в розрахунках були використані характеристики тепловидільної збірки (ТВ3) типу ТВЗА.

3 урахуванням можливості аварійного вивантаження Ак3 [14], [15] для спрощення моделювання було розглянуто один з відсіків БВ РУ 3 BВEP-1000, а саме, відсік TG21B02 з 127 відпрацьованими ТВ3 у стелажах ущільненого зберігання палива (Рисунок 1). На вибір відсіку БВ вплинуло різноманіття процесів, які відбуваються у відсіку БВ такої конструкції, і наявність організаційно-технічних заходів, таких як заборона встановлювати свіжі (слабо вигорілі) ТВ3 у неущільнені відсіки БВ [16]. 3 іншого боку, у відсіку TG21B02 достатньо повно реалізуються всі фізичні процеси, які можуть відбуватись в інших відсіках БВ.

Вважалось, що відсік завантажений одним типом ТВ3. Як консервативне завантаження розглянуто завантаження БВ свіжими (слабо-вигорілими) ТВЗА з початковим збагаченням $4,38 \%$ без урахування вигоряючого поглинача. Як більш реальне завантаження в певних 


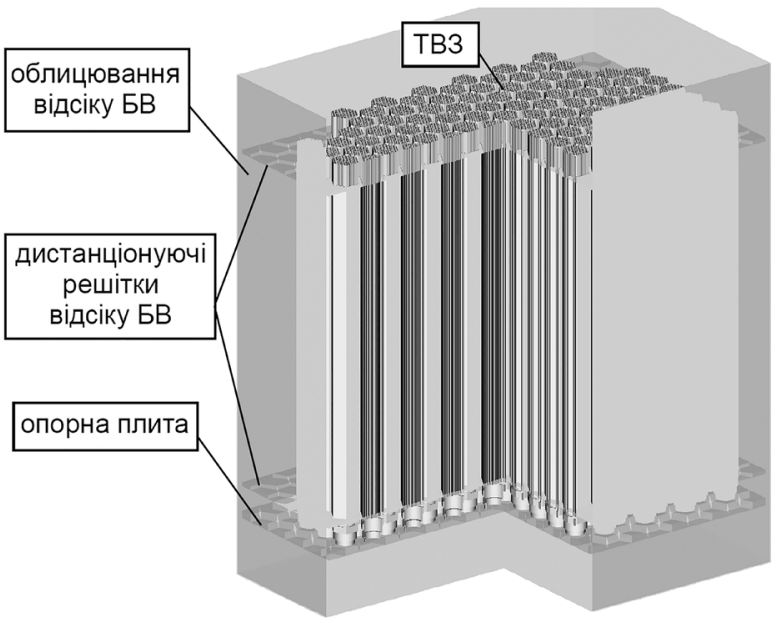

Рисунок 1 - Переріз моделі відсіку БВ TG21B02

випадках розглядалось завантаження відсіку БВ 42 ТВ3 партії підживлення (4,38 \% збагачення, глибина вигоряння $0 \mathrm{MBT} \cdot$ діб/кгU), 42 ТВ3 після 1-го року експлуатації в реакторі (глибина вигоряння 13,75 МВт · діб/кгU), 42 ТВ3 - після 2-го року (глибина вигоряння 27,5 МВт·діб/кгU), 1 ТВ3 - після 3-го року (глибина вигоряння 41,25 МВт · діб/кгU). Вигоряння для касет різного року експлуатації визначено з огляду на максимальну середню глибину вигоряння ТВЗА 55 МВт·діб/кгU [12] за умови 4-річної експлуатації палива в Ак3. Отже, з урахуванням середньої глибини вигоряння палива ТВЗА початкового збагачення 4,38\% у відсіку на рівні $\approx 14 \mathrm{MBT} \cdot$ діб/кгU, середнє збагачення ТВ3 по відсіку БВ складе 3 \%. Паливо моделювалось у вигляді суміші ізотопів ${ }^{235} \mathrm{U},{ }^{238} \mathrm{U},{ }^{239} \mathrm{Pu},{ }^{240} \mathrm{Pu},{ }^{241} \mathrm{Pu}$, та ${ }^{16} \mathrm{O}$. Вміст вигоряючого поглинача у твелах не враховувався.

Усі матеріали задавались 3 температурою $20^{\circ} \mathrm{C}$.

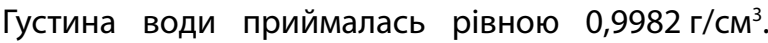
Оксидація $\mathrm{Zr}$, Fe, перехід оксидів з однієї валентності в іншу, зокрема окислення $\mathrm{UO}_{2}$ до $\mathrm{U}_{3} \mathrm{O}_{8}$, не враховувались. У [17] було показано, що врахування оксидації Zr призводить до зменшення коефіцієнта розмноження нейтронів.

На межі розрахункової моделі відсіку БВ з усіх боків, крім напрямку «вверх», задавались альбедні граничні умови відбиття на шарі бетону. У напрямку «вверх» задавались альбедні граничні умови відбиття на шарі води.

\section{2 Розроблені моделі та отримані результати}

3 початком паро-цирконієвої реакції стрімко збільшується температура оболонок твелів, що, зі свого боку, призводить до розігріву сталевих компонентів (зокрема головки ТВ3) до температури плавлення. Розплавлені сталеві компоненти стікають вниз і розігрівають опорну плиту відсіку БВ.
Пошкодження тепловидільних елементів починається після осушення активної частини ТВ3 (за деякими даними - після оголення 1/3 висоти TB3 [18]).

Нагрів головок ТВ3 до $1446{ }^{\circ} \mathrm{C}$ призведе до їхнього плавлення. Подальше підвищення температури палива зумовить плавлення оболонок твелів та утворення на опорній плиті відсіку БВ двошарової конфігурації з металічних елементів ТВ3 знизу та розсипаних окремих таблеток палива або стовпів таблеток зверху. Модель № 1 присвячена вивченню розмножуючих властивостей пошкодженого палива на цьому етапі.

У разі розплаву металічних елементів ТВЗ утвориться шар на опорній плиті БВ, максимальна товщина може скласти $\approx 50$ см, 3 них $\approx 26$ см - всередині шестигранних чохлів. Консервативно приймемо висоту шару металу від опорної плити до нижнього краю шестигранних чохлів.

Зауважимо, що опорна плита має отвори Ø 140 мм для проходу теплоносія у ТВЗ. Тому, частина металу буде проникати в ці отвори, охолоджуватись водою, що залишилась під опорної плитою, знову розігріватись, проникати нижче.

За температури $1760{ }^{\circ} \mathrm{C}$ починається реакція цирконієвої оболонки з оксидом урану палива, утворюючи складну розплавлену фазу, що містить оксиди цирконію та урану [19]. За температури в межах 2600 - $2850{ }^{\circ} \mathrm{C}$ відбувається повне розплавлення палива [20]. У разі заливу розплаву водою, вода буде утворювати тріщини, проникати в його порожнини.

Стан палива всередині шестигранних чохлів може бути змодельований за допомогою «гомогенної» та «гетерогенної» моделей (Рисунок 2), які, відповідно, моделюють водо-уранову суміш у вигляді гомогенної суміші або коріум, всередині якого утворені порожнини сферичної форми, заповнені водою (Рисунок 3). Висота стовпа коріуму/ суміші визначалась верхньою кромкою шестигранних чохлів. Цій умові відповідає співвідношення $\mathrm{V}_{\mathrm{UO2}} / \mathrm{V}_{\mathrm{H} 2 \mathrm{O}}=0,352$, і за цим значенням спостерігається найбільше значення коефіцієнта розмноження нейтронів, $\mathrm{k}_{\mathrm{e \phi}}=1,00072 \pm 0,00012$ (Рисунок 4). Однак, за умови врахування глибини вигоряння палива на рівні $14 \mathrm{MBT} \cdot д і б / к г U$ (див. розділ 1), розмножуючі властивості стають нижче, а саме: $\mathrm{k}_{\mathrm{e \phi}}=0,94896 \pm 0,00012$. Якщо ж припустити, що водо-уранова суміш має температуру $100{ }^{\circ} \mathrm{C}$, то тоді значення коефіцієнта розмноження нейтронів слабовигорілого палива становить $\mathrm{k}_{\mathrm{e} \phi}=0,97449 \pm 0,00012$.

Отже, досягнення критичності на цій стадії буде залежати від таких факторів, як склад завантаження відсіку витримки та температура суміші.

Найімовірніше, на цьому етапі почнеться плавлення шестигранних чохлів, оскільки виникне надійний контакт розплаву з чохлами. 

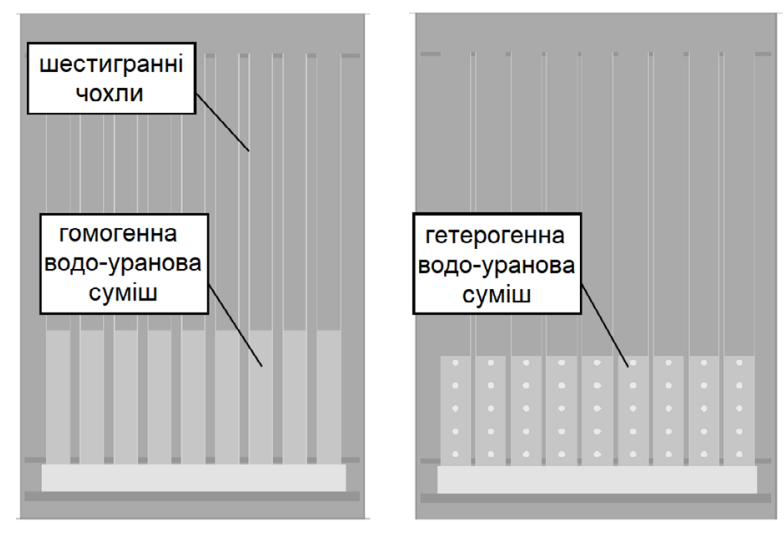

Рисунок 2 - Моделювання заповнення шестигранних труб гомогенною (зліва) та гетерогенною (справа) водоурановою сумішшю

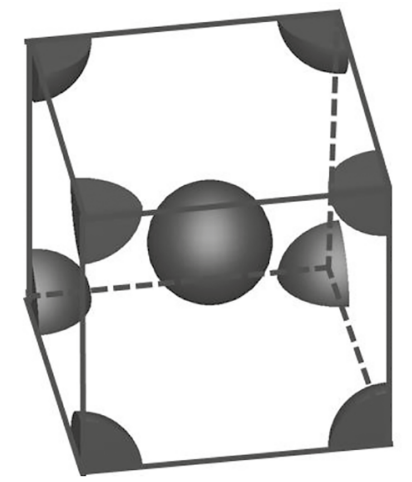

Рисунок 3 - Моделювання гетерогенної водо-урановою суміші. Показані заповнені водою порожнини в коріумі

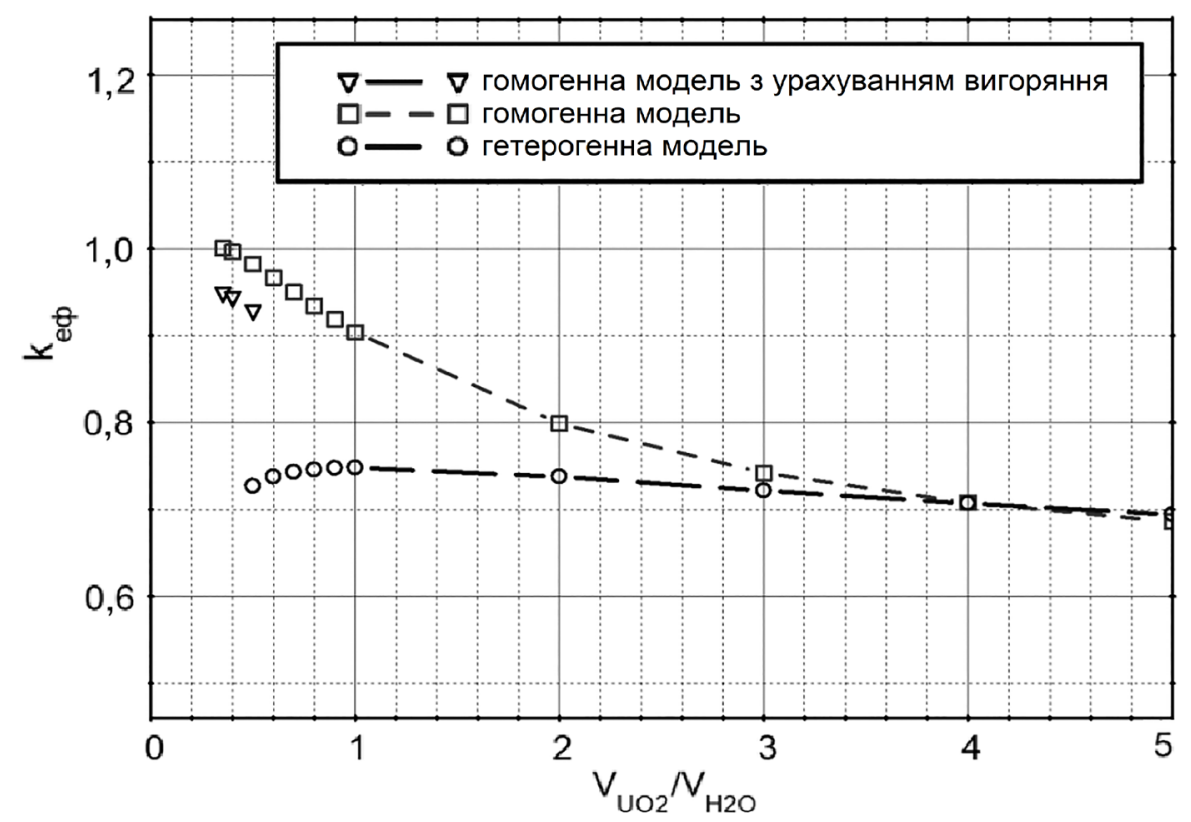

Рисунок 4 - Результати розрахунків критичності пошкодженого палива

Процес плавлення шестигранних труб моделюється як поступове видалення труб по 1/10 їх висоти зверху вниз. Уважається, що шестигранні труби заповнені гомогенною водоурановою сумішшю, параметри якої відповідають найбільшому значенню коефіцієнта розмноження нейтронів, Рисунок 4.

Зменшення висоти шестигранних труб моделювалось двома варіантами. Перший з них, найпростіший - зменшення висоти чохлів на 1/10 (36 см) без зміни геометрії водо-уранової суміші всередині них, Рисунок 5.

Проте, утворення шестигранних призм висотою 360 см 3 повністю гомогенної суміші палива та

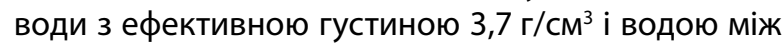

ними $\epsilon$ малоімовірним. 3 іншого боку, потрібно зважати на можливість появи зависі під час робіт 3 ліквідації аварії. За таких обставин частина суміші буде знаходитись у верхній частині стелажів, позбавленій чохлів, і саме вона буде визначати розмножуючі властивості відсіку БВ (Рисунок 6). Оскільки верхня частина стелажів буде позбавлена шестигранних чохлів, водо-уранова суміш сусідніх чарунок легко з'єднується і перемішується.

Проте, як показують результати моделювання, незалежно від конфігурації водо-уранової суміші, у разі зменшення висоти шестигранних чохлів за умови формування всередині них водо-уранової суміші оптимального співвідношення $\mathrm{V}_{\mathrm{UO2}} / \mathrm{V}_{\mathrm{H} 2 \mathrm{O}^{\prime}}$ можливе виникнення критичності (Рисунок 7). 

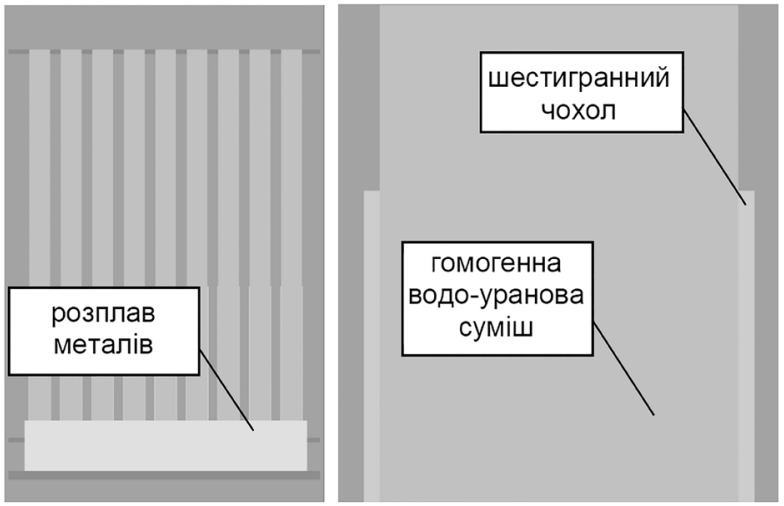

Рисунок 5 - Переріз відсіку БВ з гомогенною водоурановою сумішшю всередині чохлів (зліва) і переріз окремої чарунки (справа)

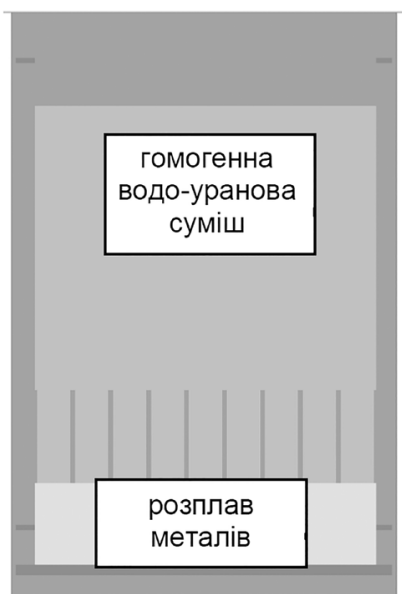

Рисунок 6 - Переріз відсіку БВ з гомогенною водо-урановою сумішшю у разі утворення зависі

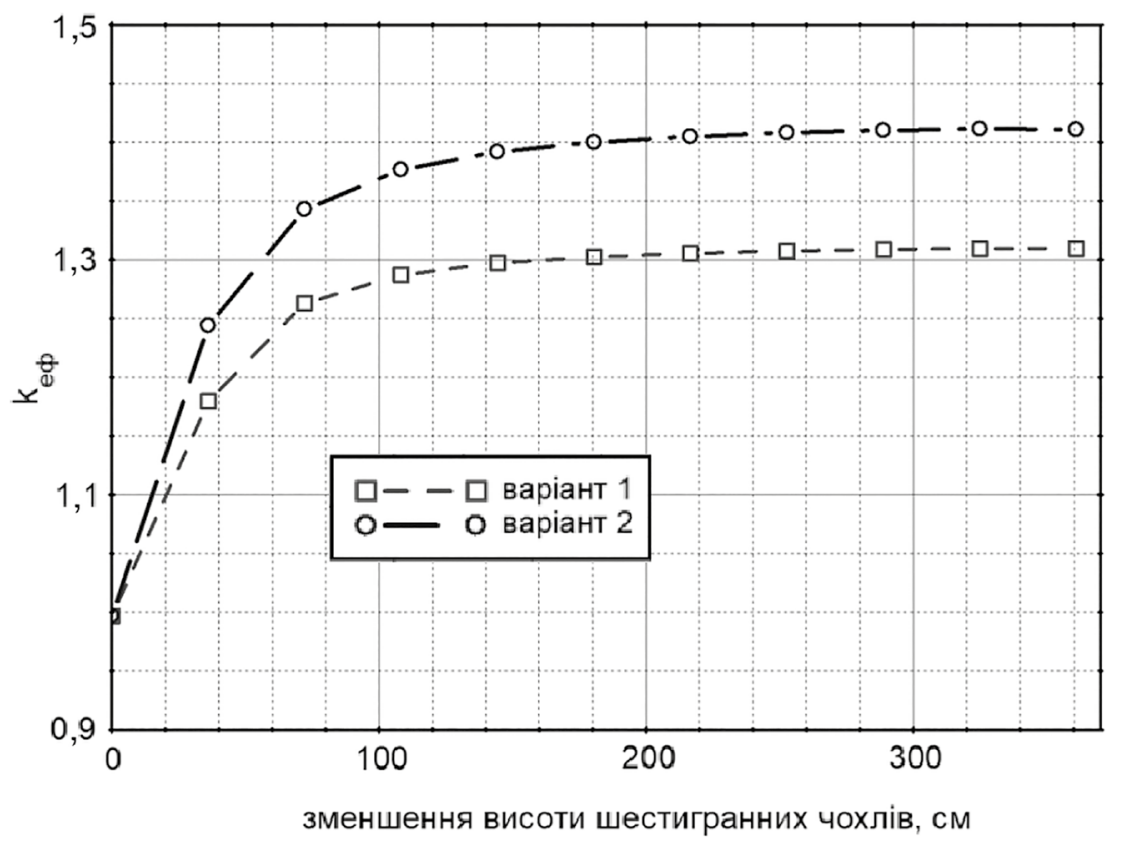

Рисунок 7 - Результати розрахунків критичності у разі зменшення висоти абсорбційних чохлів

На Рисунку 7 зображені результати розрахунків розмножуючих властивостей вищенаведених варіантів деградації шестигранних чохлів. На Рисунку 7 конфігурація «варіант 1» відповідає Рисунку 5, «варіант 2» - Рисунку 6. Як можна зазначити за результатами розрахунків, після зниження висоти шестигранних чохлів на $\approx 1 / 3$ висоти, розмножуючі властивості відсіку БВ будуть визначатися частиною палива, вільною від шестигранних чохлів.

У разі перебігу важкої аварії у відсіку БВ з неущільненими стелажами, ця стадія аварії буде відсутня.
Повне розплавлення відсіку БВ над опорною плитою призведе до появи двошарової системи (оскільки металеві елементи розплавились першими), а потім - до умовно гомогенної системи, оскільки внаслідок різної густини складових розплав $\mathrm{UO}_{2}$ може переміщатись униз (Рисунок 8). 3 огляду на аналіз критичності становить інтерес продовження процесу - коли розплав $\mathrm{UO}_{2}$ переміщується вниз («перевернута гетерогенна» модель на Рисунку 8), і через отвори в опорній плиті витікає у простір під опорною плитою. Результат розрахунків коефіцієнта розмноження нейтронів таких систем наведено в Таблиці 2. 
Оскільки борована сталь шестигранних чохлів містить суміш боридів $\mathrm{Ti}, \mathrm{Fe}, \mathrm{Cr}$ та V ([21], [22]), існує можливість їхнього видалення з розплаву у вигляді кірки різного роду відкладень. Тому, в Таблиці 2 наведено також результати розрахунку змодельованих систем без врахування бору в сталі.

Упродовж плавлення стальних елементів ТВ3, вони стікають униз, охолоджуючись, і нагріваючи саму плиту. Водночас можливе потрапляння стовпів таблеток або затягнення частини палива потоком металу в отвір. Утім, якщо паливо зможе потрапити під опорну плиту з незначними домішками сталі, воно, у разі контакту з водою, буде розтріскуючись застигати. Гіпотетично паливо буде утворювати краплевидну, в ідеалі (з погляду витоку нейтронів) - сферичну форму водо-уранової суміші.

Оскільки чарунка відсіку БВ має відносно невеликі розміри - розмір «під ключ» становить 28,8 см - авторами було вирішено змоделювати уран-водну суміш у сфері таким самим діаметром.

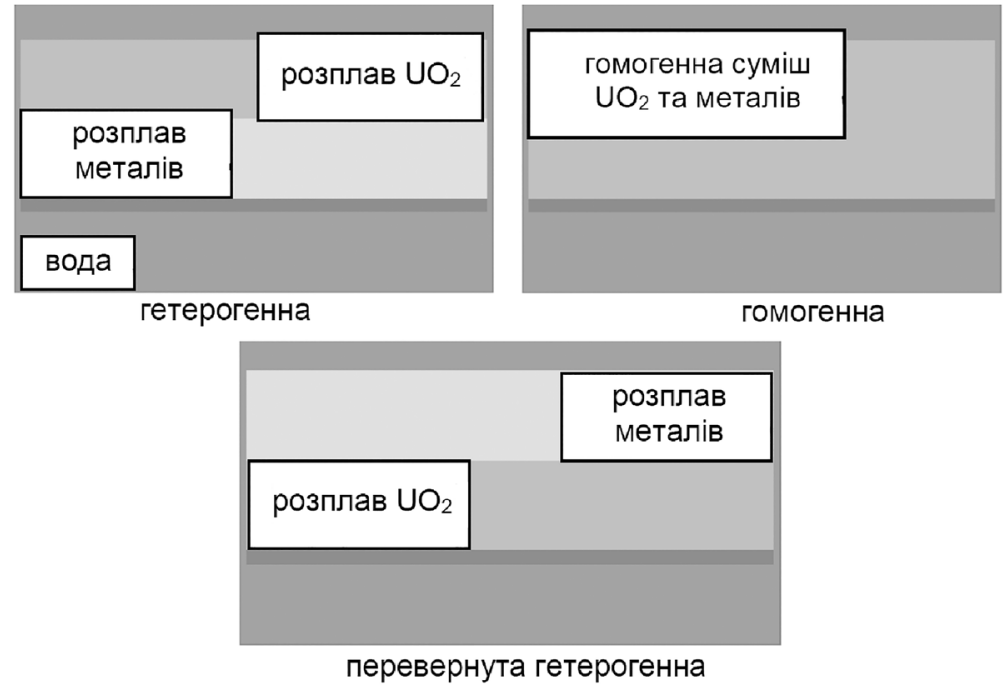

Рисунок 8 - Моделі коріуму над опорною плитою відсіку БВ

Таблиця 2 - Розмножуючі властивості коріуму над опорною плитою відсіку БВ

\begin{tabular}{|l|c|}
\hline \multicolumn{1}{|c|}{ Конфігурація коріуму } & $\mathrm{k}_{\text {eф }} \pm \sigma$ \\
\hline $\begin{array}{l}\text { Двошарова модель розтікання коріуму по опорній плиті (Рисунок 8, } \\
\text { гетерогенна модель) }\end{array}$ & $0,729569 \pm 0,000075$ \\
\hline $\begin{array}{l}\text { Двошарова модель розтікання коріуму по опорній плиті (Рисунок 8, } \\
\text { гетерогенна модель) без врахування бору у сталі шестигранних чохлів }\end{array}$ & $0,732147 \pm 0,000076$ \\
\hline $\begin{array}{l}\text { Гомогенна модель розтікання коріуму по опорній плиті (Рисунок 8, } \\
\text { гомогенна модель) }\end{array}$ & $0,527836 \pm 0,000056$ \\
\hline $\begin{array}{l}\text { Гомогенна модель розтікання коріуму по опорній плиті (Рисунок 8, } \\
\text { гомогенна модель) без врахування бору сталі шестигранних чохлів }\end{array}$ & $0,587490 \pm 0,000061$ \\
\hline $\begin{array}{l}\text { Двошарова модель розтікання коріуму по опорній плиті (Рисунок 8, } \\
\text { перевернута гетерогенна модель) }\end{array}$ & $0,679106 \pm 0,000061$ \\
\hline
\end{tabular}


Аналіз можливості виникнення критичності проведено, як і раніше, за допомогою «гомогенної» та «гетерогенної» моделей (Рисунок 9 та Рисунок 10 відповідно) перемішування палива та води. Гетерогенна конфігурація моделювалась аналогічно наведеній на Рисунку 3. Отримані результати наведені на Рисунку 11.

Як можна зазначити за результатами розрахунків, наведених на Рисунку 11, для співвідношення $\mathrm{V}_{\mathrm{UO2}} / \mathrm{V}_{\mathrm{H} 2 \mathrm{O}}=0,4-0,5$ спостерігається найвище значення коефіцієнта розмноження нейтронів: $\mathrm{k}_{\mathrm{e \phi}}=1,10856 \pm 0,00013$ для гомогенної суміші та $\mathrm{k}_{\text {еф }}=1,14369 \pm 0,00012$ - для гетерогенної. I таку надкритичність вже неможливо скомпенсувати врахуванням вигоряння палива

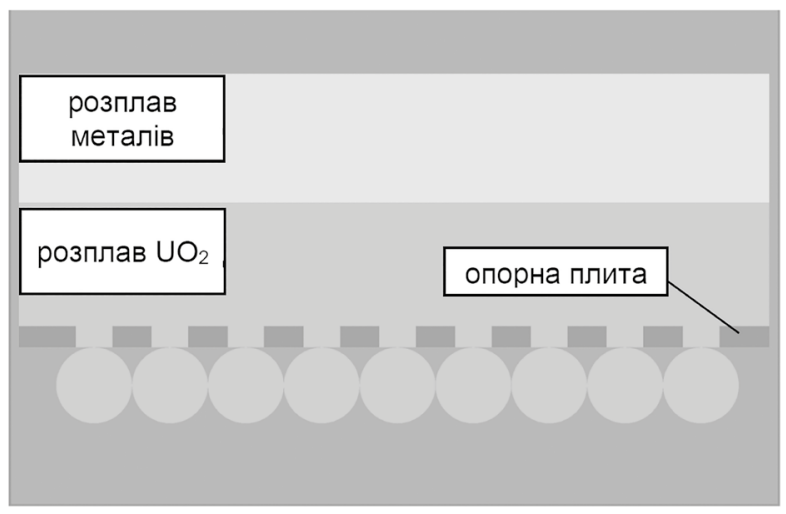

Рисунок 9 - Модель гомогенної водо-уранової суміші під опорною плитою відсіку БВ або температурними ефектами. Зниження $\mathrm{k}_{\mathrm{e}}$ можна очікувати внаслідок заповнення відсіку БВ водою з розчином бору або у разі, коли коріум буде складатись не тільки з $\mathrm{UO}_{2}$, а і з розплаву металів, завдяки чому $\mathrm{UO}_{2}$ буде «розбавлений» до безпечного вмісту.

Далі відбувається пошкодження опорної плити БВ і витікання металів у воду, яка залишилася. Конфігурація коріуму в Моделі № 2 найімовірніше, принаймні на початку процесу, буде близька до гомогенної суміші матеріалів ТВ3, чохлів та опорної плити відсіку БВ. Також, можливе утворення інших конфігурацій, подібних до наведених на Рисунку 8, коли паливо розташоване зверху або знизу шару розплаву металів.

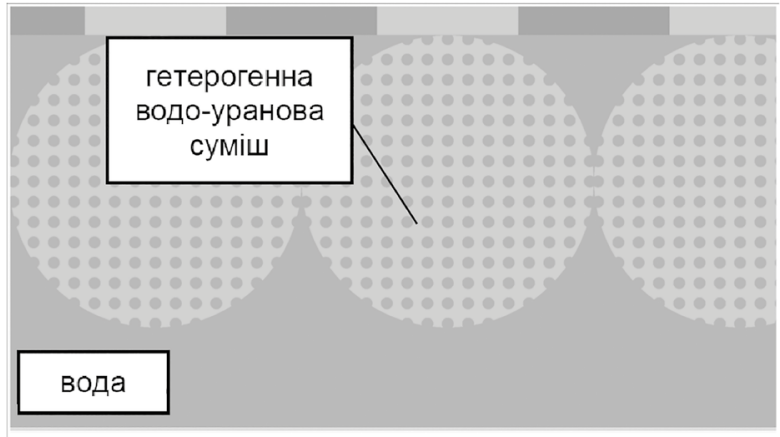

Рисунок 10 - Модель гетерогенної водо-уранової суміші під опорною плитою відсіку БВ

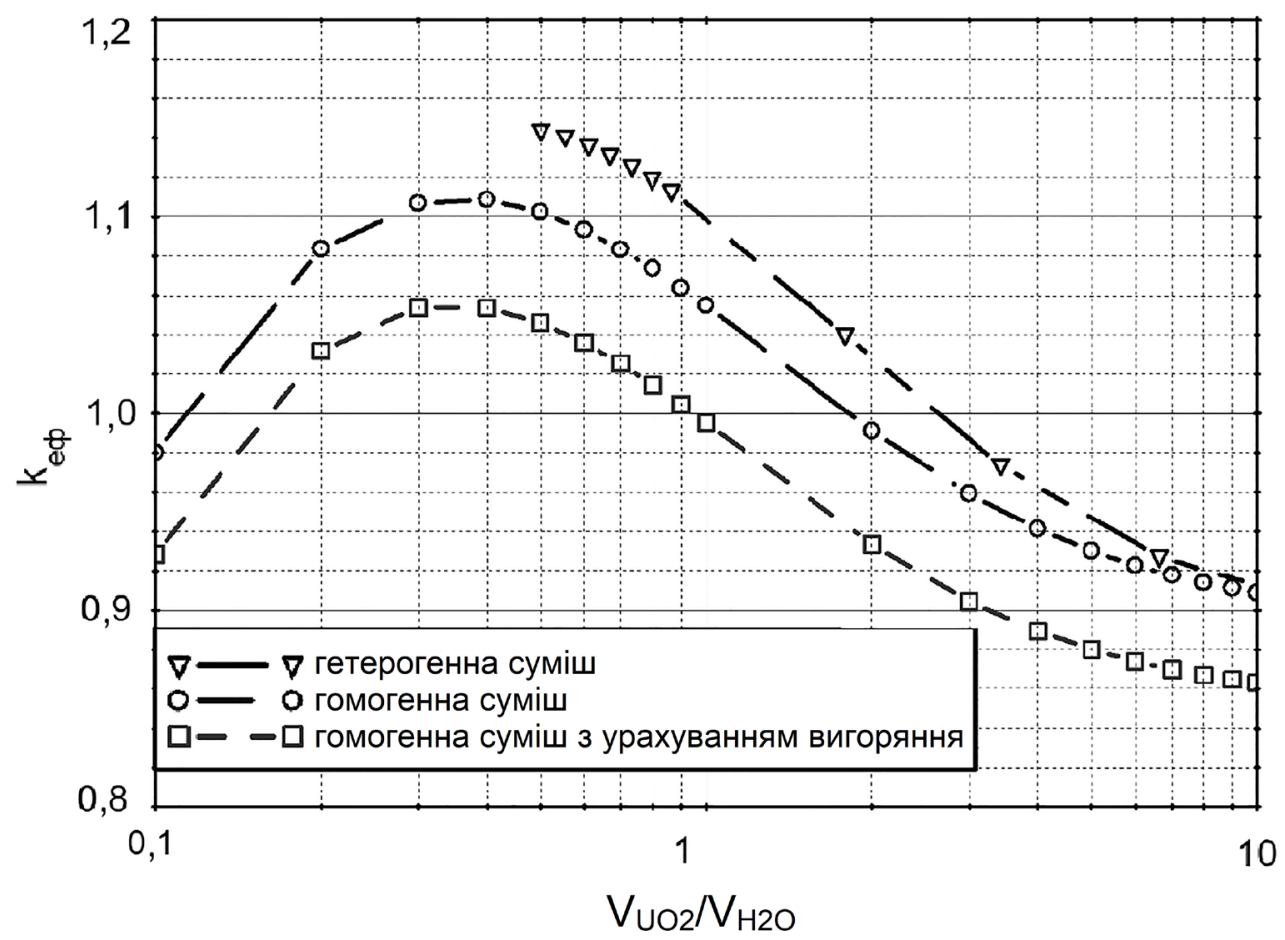

Рисунок 11 - Результати розрахунків критичності водо-уранової суміші під опорною плитою відсіку БВ 
Після повного осушення БВ пошкоджується його облицювання i починається взаємодія розплаву 3 бетоном будівельних конструкцій підлоги БВ.

Водночас, оскільки бетон $\epsilon$ гіршим уповільнювачем нейтронів ніж вода, коефіцієнт розмноження нейтронів буде нижчим, ніж у розглянутих вище конфігураціях коріуму. Розглянемо найпростішу та найконсервативнішу конфігурацію проплавлення бетону - напівсферичну. У схожій за тематикою роботі [23] масова доля бетону в суміші складала до 0,452 вагової частки. Що відповідає $\approx 0,8$ об'ємної частки. Тому Модель № 3 буде складатись із напівсферичної конфігурації суміші коріуму та бетону 3 часткою бетону в ній 0 - 90 \%. Хімічний склад компонентів моделювався сталим. Відповідно до вмісту бетону змінювався радіус проплавлення.

У разі заливу суміші коріуму з бетоном водою малоймовірне утворення гомогенної суміші внаслідок того, що з бетону будуть випаровуватись гази, які будуть утворювати порожнини, пузирі в коріумі (див. [24], [25]). Тому, цілком прийнятною буде модель гетерогенної суміші, використаної вище і показаної на Рисунку 3. Враховуючи, що у разі зміни частки бетону в розплаві $\mathrm{k}_{\text {еф }}$ змінюється несуттєво $\left(\mathrm{k}_{\mathrm{e \phi}}=0,515-0,556\right)$, для аналізу впливу наявності води в коріумі був вибраний варіант суміші коріуму з 90 \% бетону, оскільки він має найбільший розмір з розглянутих (радіус напівсфери $\approx 4$ м). Результати розрахунку розмножуючих властивостей за зміни вмісту води наведено на Рисунку 14.

Згідно $з$ наведеними на Рисунку 14 результатами розрахунків, у разі додавання води можливе несуттєве підвищення коефіцієнта розмноження нейтронів $3 \mathrm{k}_{\text {еф }}=0,525571 \pm 0,000046$ до $\mathrm{k}_{\mathrm{e \phi}}=0,536025 \pm 0,000048$. Проте, розглянута суміш $\epsilon$ глибоко підкритичною.

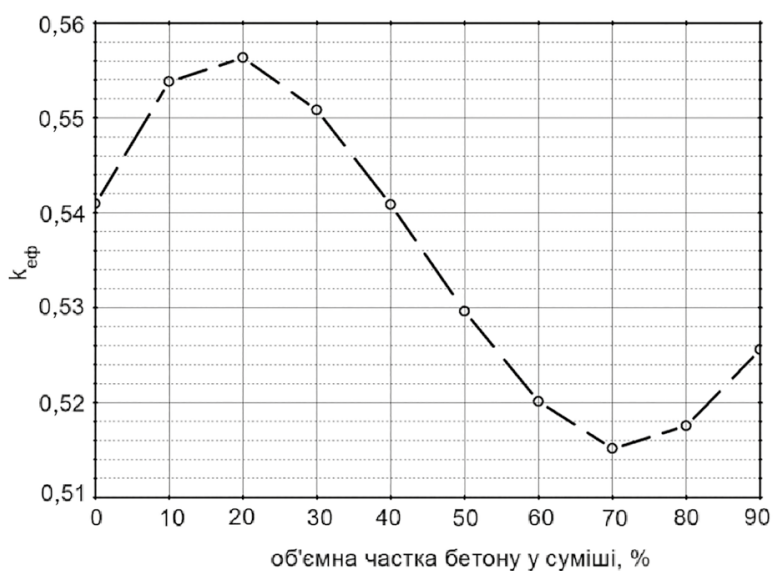

Рисунок 13 - Результати розрахунків критичності у разі проплавлення бетону відсіку БВ
Завдяки врахуванню конструкційних матеріалів відсіку БВ та ТВ3, використанню близької до реальної геометрії коріуму, отримані значення $\mathrm{k}_{\text {еф }}$ набагато менше, наведених у [26] для консервативних розрахунків нескінченного коефіцієнта розмноження нейтронів суміші $\mathrm{UO}_{2}$ та бетону.

\section{Висновки}

У статті розглянуто розроблені з використанням коду KENO-VI 3 послідовності для аналізу критичності CSAS6 пакету кодів SCALE версії 6.2.4 моделі та результати виконаних розрахунків розмножуючих властивостей паливомістких мас під час перебігу важкої аварії у відсіках БВ РУ з реакторами ВBEP-1000.

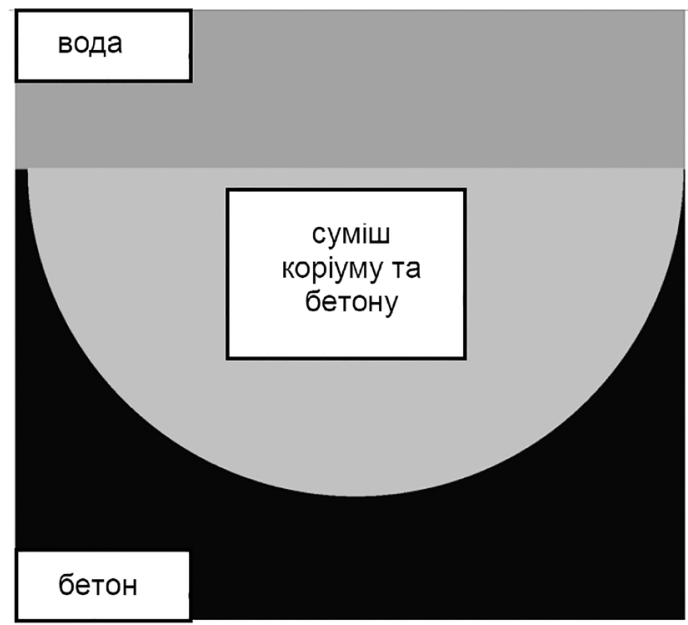

Рисунок 12 - Модель проплавлення бетону

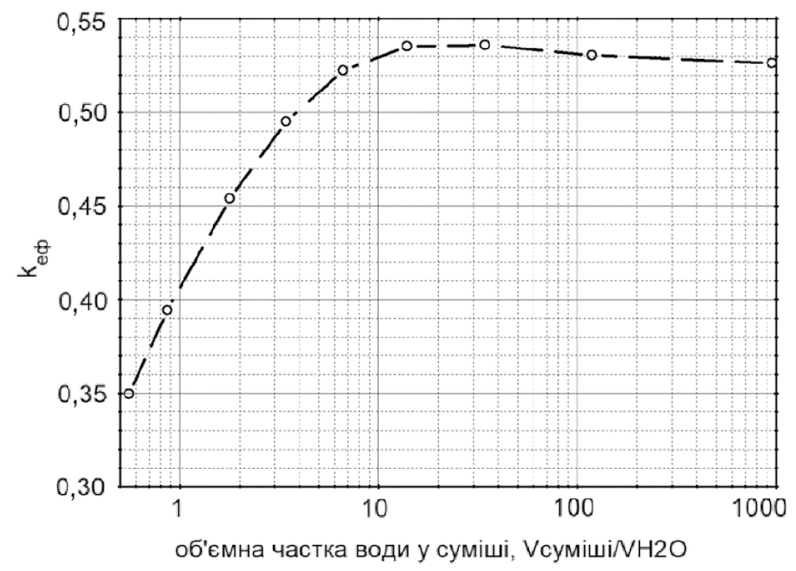

Рисунок 14 - Результати розрахунків критичності у разі заливу водою суміші коріуму та бетону 
Наведені в статті результати розрахунків ефективного коефіцієнта розмноження нейтронів свідчать, що завдяки наявності поглинаючого матеріалу в сталі шестигранних чохлів, їх цілісність забезпечує необхідний рівень підкритичності відсіку БВ. Для неущільнених секцій відсіку БВ характерний перехід у надкритичний стан навіть за умов проєктних аварій [27]. Це підтверджується розрахунками ефективного коефіцієнта розмноження нейтронів в умовах деградації (зниженням висоти) шестигранних чохлів. У всіх розглянутих конфігураціях водо-уранової суміші була досягнута надкритичність. За таких умов необхідний рівень підкритичності може бути забезпечений розчином бору у воді.

Розглянута модель розтікання коріуму по опорній плиті $\epsilon$ безпечною 3 погляду на критичність.

Коли розплав або уламки палива $\left(\mathrm{UO}_{2}\right)$ потраплять через отвори для проходу теплоносія у простір під опорну плиту, вони можуть утворити з залишками води уран-водну суміш, яка за певних співвідношень $\mathrm{V}_{\mathrm{UO2}} / \mathrm{V}_{\mathrm{H} 2 \mathrm{O}}$ може стати надкритичною. У такому випадку розмножуючі властивості відсіку БВ будуть залежати від вмісту домішків конструкційних елементів БВ та ТВЗ у матеріалі під опорною плитою та/або концентрації борної кислоти у воді.

Після пошкодження сталі підлоги відсіку БВ, починається проплавлення бетону. Розглянуті конфігурації та матеріальний склад суміші коріуму, бетону та води дозволяють зробити висновок про безпечність цієї фази важкої аварії з погляду на критичність.

\section{Список використаної літератури}

1. Jamet P. European Union Response to Fukushima European Stress Tests and Peer Review. $38^{\text {th }}$ MPA-Seminar. October 1 and 2, 2012. MPA University of Stuttgart, Germany. P. 21-25.

2. National Report for Finland on EU Nuclear Stress Tests. 2012. URL: http://www.ensreg.eu/node/361 (дата звернення: 10.08.2021).

3. National Report for France on EU Nuclear Stress Tests. 2012. URL: http://www.ensreg.eu/node/371 (дата звернення: 10.08.2021)

4. National Report for Germany on EU Nuclear Stress Tests. 2012. URL: http://www.ensreg.eu/node/360 (дата звернення: 10.08.2021)

5. National Report for Spain on EU Nuclear Stress Tests. 2011. URL: http://www.ensreg.eu/node/357 (дата звернення: 10.08.2021).

6. National Report for Sweden on EU Nuclear Stress Tests. 2011. URL: http://www.ensreg.eu/node/358 (дата звернення: 10.08.2021)
7. National Report for the Slovak Republic on EU Nuclear Stress Tests. 2012. URL: http://www.ensreg.eu/node/366 (дата звернення: 10.08.2021).

8. Peer review report. Stress tests performed on European nuclear power plants. ENSREG, 25.04.2012.

9. ПМ Т.0.41.414-15. Программа работ по анализу аварийных феноменов тяжелых аварий. ДП «НАЕК «Енергоатом», 2015. Погоджена листом Держатомрегулювання № 15-28/131 від 11.01.2016.

10. Виконання аналізів критичності для важких аварій. Звіт з Завдання № 19 до угоди № 358160 між Брукхевенською Національною Лабораторією та ДНТЦ ЯРБ від 09.09.2020 року (остаточний), погоджений листом Держатомрегулювання № 15-34/3497 від 12.04.2021. К.: ДНТЦ ЯРБ, 2021.

11. Wieselquist W. A., Lefebvre R. A., Jessee M. A., Eds. SCALE Code System. ORNL/TM-2005/39. Version 6.2.4, Oak Ridge, Tennessee: Oak Ridge National Laboratory, 2020.

12. Комплекс составных частей активной зоны ВВЭР-1000 (тип В-320, В-338, В-302). Каталожное описание. У0401.21.00.000 ДКО. ПАО НЗКХ, 2003.

13. WEC-RWFA-001(T). Технические условия на упрочненную ТВС компании «Вестингауз» для реактора ВВЭР-1000. Редакция 8, Июнь 2019.

14. НП 306.2.141-2008. Загальні положення безпеки атомнихстанцій.Затвердженінаказом Держатомрегулювання України від 19.11.2007 № 162, зареєстровані в М-ві юстиції України 25.01.2008 за № 56/14747.

15. Guidance Document. Issue F: Design Extension of Existing Reactors. WENRA RHWG. 29 September 2014.

16. Об обеспечении ядерной безопасности при обращении со свежим и отработавшим ядерным топливом на энергоблоках ВВЭР АЭС Украины и о снижении избыточного консерватизма: концептуальне технічне рішення. ОП НТЦ НАЕК, 2011. Погоджене листом Держатомрегулювання № 15-29/304 від 16.01.2012.

17. Bilodid le., Dudka O., Kovbasenko Yu. Analysis of corium criticality in VVER-440 during severe accident. 29th Symposium of AER on VVER Reactor Physics and Reactor Safety (2019, Energoland, Mochovce NPP, Slovakia).

18. Severe accident management guidance technical basis report - volume 2: the physics of accident progression. Palo Alto: EPRI; 2012. (Report No. 1025295).

19. Safety and Security of Commercial Spent Nuclear Fuel Storage: Public Report. Washington: National Research Council. 2006. 126 p. doi: $10.17226 / 11263$.

20. Hofmann P. Current knowledge on core degradation phenomena, a review. Journal of Nuclear Materials. 1999. No. 270. P. 194-211.

21. Кадач М. В., Гамин Ю. В., Солонин А. Н., Поздняков А. В. Профилирование трубы круглого сечения в шестигранную из стали с повышенным содержанием бора. Известия Высших Учебных Заведений. Черная Металлургия. 2014. № 57(11). С. 11 - 14. doi: 10.17073/0368-0797-2014-11-11-14.

22. Губенко С.И., Беспалько В.Н. Трансформация боридных включений при производстве труб для атомной энергетики. Строительство, материаловедение, машиностроение: Стародубовские чтения. 2018, С.107 - 112. 
23. Безбородов А. Н., Меркулов В. В. Теплофизический анализ и анализ ядерной безопасности бассейна выдержки при аварии с полным длительным обесточиванием АЭС. Материалы конференции «Обеспечение безопасности АЭС с ВВЭР» (Подольск, ОКБ «Гидропресс», 19 -22 мая 2015 г.). Подольск : ОКБ «Гидропресс», 2015. С. 95 -110.

24. Freiría López M., Buck M., Starflinger, J. Criticality Characteristics and Sensitivity Analysis of Fukushima Debris Beds Containing MCCI Products. ASME Journal of Nuclear Engineering and Radiation Science. 2020. 6(4): 041110.

25. Sevón T. Molten Core - Concrete Interactions in Nuclear Accidents: Theory and Design of an Experimental Facility. Espoo: VTT Tiedotteita - Research Notes 2311. 2005. $83 \mathrm{p}$.

26. Izawa K., Uchida Yu., Ohkubo K., Totsuka M., Sono H., Tonoike K. Infinite multiplication factor of low-enriched $\mathrm{UO}_{2}-$ concrete system. Journal of Nuclear Science and Technology. 2012. Vol. 49, No. 11. P. 1043 - 1047.

27. Запорожская АЭС. Энергоблок № 1-5. Дополнение к материалам АПА ТТО «Анализ ядерной безопасности для отсеков БВ энергоблоков ОП ЗАЭС, которые оборудованы неуплотненными стеллажами ПО «Ижорские заводы», с учетом реализованных организационно-технических мероприятий». Расчеты ядерной безопасности для отсеков БВ, которые оборудованы неуплотненными стеллажами ПО «Ижорские заводы». 21.1-5.59.0Б.02.02: звіт. Погоджений листом Держатомрегулювання від 17.07.2012 № 15-33/4-4439.

\section{References}

1. Jamet P. European Union Response to Fukushima European Stress Tests and Peer Review. 38 $8^{\text {th }}$ MPA-Seminar. MPA University of Stuttgart, Germany. October 1 and 2, 2012. pp. 21-26. European Union Response to Fukushima - European Stress Tests and Peer Review. 38 ${ }^{\text {th }}$ MPA-Seminar. MPA University of Stuttgart, Germany. October 1 and 2, 2012. pp.21-26.

2. National Report for Finland on EU Nuclear Stress Tests. (2012). Retrieved August 10, 2021 from http://www.ensreg.eu/ node/361.

3. National Report for France on EU Nuclear Stress Tests. (2012). Retrieved August 10, 2021 from http://www.ensreg.eu/ node/371.

4. National Report for Germany on EU Nuclear Stress Tests. (2012). Retrieved August 10, 2021 from http://www.ensreg.eu/ node/ 360 .

5. National Report for Spain on EU Nuclear Stress Tests. (2011). Retrieved August 10, 2021 from http://www.ensreg.eu/ node/357.

6. National Report for Sweden on EU Nuclear Stress Tests. (2011). Retrieved August 10, 2021 http://www.ensreg.eu/ node/358.

7. National Report for the Slovak Republic on EU Nuclear Stress Tests. (2012). Retrieved August 10, 2021 from http://www.ensreg.eu/node/366.
8. Peer review report. Stress tests performed on European nuclear power plants. ENSREG, 25 April 2012.

9. PM T.0.41.414-15. Program of Activities on Analysis of Severe Accident Phenomena. SE "NNEGC "Energoatom", 2015. Agreed by the SNRCU letter on January 11, 2016 for № 15-28/131.

10.Criticality Analyses for Severe Accidents (Task No. 19, BOA No. 358160 between BNL and SSTC NRS dated 09 September 2020). approved by the SNRIU, letter on 12.04.2021 for № 15-34/3497. SSTC NRS, Kyiv, 2021, 58 p.

11. Wieselquist, W. A., Lefebvre, R. A. and Jessee, M. A., Eds. SCALE code system. (2020). ORNL/TM-2005/39, Version 6.2.4, Oak Ridge National Laboratory, Oak Ridge, Tennessee.

12. Set of component parts of WWER-1000 core (V-320, V-338, V-302). Catalog description. U0401.21.00.000 DKO. PJSC Novosibirsk Chemical Concentrates Plant (NCCP), 2003.

13. WEC-RWFA-001(T) Technical specifications for strengthened Westinghouse FA for VVER-1000. Revision 8, June 2019.

14. NP 306.2.141-2008 General safety provisions for nuclear power plants. Approved by SNRIU Order No. 162 of 19 November 2007, registered in the Ministry of Justice of Ukraine on 25 January 2008 under No. 56/14747.

15. WENRA RHWG Guidance Document Issue F: Design Extension of Existing Reactors. 29 September 2014.

16. Concept technical solution "On nuclear safety during fresh and spent nuclear fuel management at WWER NPPs of Ukraine and on reducing excessive conservatism". Energoatom STC, 2011. Agreed by SNRIU Order No. 15-29/304 of 16 January 2012.

17. Bilodid, le., Dudka, O., Kovbasenko, Yu. (2019). Analysis of corium criticality in VVER-440 during severe accident. $29^{\text {th }}$ Symposium of AER on VVER Reactor Physics and Reactor Safety. Energoland, Mochovce NPP, Slovakia.

18. Electric Power Research Institute - EPRI. Severe accident management guidance technical basis report, volume 2: the physics of accident progression. (2012). Palo Alto: EPRI. (Report No. 1025295).

19. National Research Council. 2006. Safety and security of commercial spent nuclear fuel storage: public report. Washington, DC: the National Academies Press. doi: org/10.17226/11263.

20. Hofmann P. (1999). Current knowledge on core degradation phenomena, a review. Journal of Nuclear Materials. 270. 194-211.

21. Kadach, M., Gamyn Yu., Solonin, A., Pozdniakov, A. (2014). Profiling of a circular tube into a hexagon pipe of steel with increased boron content. News of Higher Educational Institutions. Ferrous Metallurgy, 57(11), 11 - 14. doi: 10.17073/0368-0797-2014-11-11-14.

22. Gubenko, S., Bespalko, V. (2018). Transformation of boride inclusions in the production of piping for nuclear power. Construction, Materials Science, Mechanical Engineering: Starodubovskyi Readings, $107-112$.

23. Bezborodov, A., Merkulov, V. Thermophysical analysis and nuclear safety analysis of the spent fuel pool under an accident with complete NPP blackout. Documents of conference "WWER NPP safety". Podolsk, EDO Gidropress, 19- 22 May 2015, $95-110$. 
24. Freiría López, M., Buck, M., and Starflinger, J. (4 September 2020). Criticality characteristics and sensitivity analysis of Fukushima debris beds containing MCCl products. ASME. ASME Journal of Nuclear Engineering and Radiation Science. October 2020, 6(4), 041110. doi: 10.1115/1.4047094.

25. Sevón, T. (2005). Molten core - concrete interactions in nuclear accidents: theory and design of an experimental facility.

26. Izawa K., Uchida Yu., Ohkubo K., Totsuka M., Sono H., Tonoike K. (2012). Infinite multiplication factor of low-enriched $\mathrm{UO}_{2}$-concrete system, Journal of Nuclear Science and Technology, 49:11, 1043-1047, doi: 10.1080/00223131.2012.730893.

27. Zaporizhzhya NPP. Power Units 1-5. Supplement to DBAA for handling operations "Nuclear safety analysis for SFP compartments of ZNPP units equipped with uncompacted racks of the Izhora plants, taking into account the implemented organizational and technical measures". Calculations of nuclear safety for SFP compartments equipped with uncompacted racks at the Izhora plants. 21.1-5.59. OB.02.02: Report. Agreed by SNRIU letter No. 15-33/4-4439 of 17 July 2012.

\section{Criticality Analysis of a Severe Accident in VVER-1000 Reactor Pool}

\section{Bilodid le., Dudka O., Kovbasenko Yu.}

State enterprise «State Scientific and Technical Center for Nuclear and Radiation safety», Kyiv, Ukraine

The article presents the results of the calculation analysis of the criticality of the reactor pool compartment for VVER-1000 reactors at different stages of a severe accident.

The criticality analysis of fuel-containing systems formed during the development of a severe accident is considered on the example of several discrete configurations that can be described by certain models. In reality, the course of a severe accident will be a continuous process of transition from the initial stage of the accident to its steady state at the end. However, depending on the fuel characteristics and conditions of development of a severe accident, any considered configuration of fuel assemblies and reactor pool materials may become final. The article presents a criticality analysis of the reactor pool compartment of the VVER-1000 reactor unit at the severe accident stages following the deformation of fuel rods and fuel assemblies at the initial stage of the accident due to water boil-off and temperature increase.
On the basis of the models developed, the multiplication properties of the reactor pool compartment in the conditions of degradation of hexagonal tubes were investigated. Supercriticality (i.e. multiplication factor was greater than 1) was achieved in all two considered configurations of the water-uranium mixture. That is, under such conditions, the required level of subcriticality can be provided by a boron solution in water. The considered homogeneous single-layer and two-layer model of corium spreading on the support plate is safe in terms of criticality. However, the support plate has holes for the passage of the coolant to the fuel assembly. In the case when the melt or fuel debris enters the space under the support plate through these holes, they can form a uranium-water mixture with the remaining water, which at certain fuel and water ratios can become supercritical. In this case, the multiplication properties of the reactor pool compartment will depend on the ratio of impurities of the reactor pool and fuel assembly structural elements in the material under the support plate and/or the concentration of boric acid in the water. After damage of the reactor pool compartment floor, the melting of concrete begins. The considered configurations and material composition of the mixture of corium, concrete and water allow us to make a conclusion about the safety of this phase of a severe accident in terms of criticality.

Keywords: criticality, reactor pool, VVER-1000, severe accident, melt, criticality safety, SCALE, KENO-VI.

Отримано 01.07.2021 